\title{
The effect of chronic fluoxetine administration on anxiety-like behavior and expression of 5-HT- related proteins in rats with constitutively altered 5-HT homeostasis
}

\author{
Maja Kesić, Jasminka Štefulj, Gordana Mokrović, Lipa Čičin-Šain* \\ From 18th Scientific Symposium of the Austrian Pharmacological Society (APHAR). Joint meeting with the \\ Croatian, Serbian and Slovenian Pharmacological Societies. \\ Graz, Austria. 20-21 September 2012
}

\section{Background}

Serotonin (5-HT), a monoamine neurotransmitter/neuromodulator widely distributed in the brain, plays an important role in variety of behaviors and behavioral disorders including anxiety and depression. Therapeutic effects of fluoxetine, a widely prescribed selective serotonin reuptake inhibitor (SSRI), include inhibition of 5-HT transporters (SERT) and desensitization of $5-\mathrm{HT}_{1 \mathrm{~A}}$ receptors which leads to the enhancement of 5-HT transmission. The patient's ability to respond to treatment with fluoxetine (and other SSRIs) is greatly variable and genetic SERT variants, which are believed to influence serotonergic neurotransmission, might influence interindividual variability in the pharamacotherapeutic response. In our research we use Wistar-Zagreb 5HT rats, an animal model with constitutively high or low SERT activity (termed high-5HT and low-5HT subline), developed by selective breeding toward extremes of this parameter in our laboratory. In addition to differential regulation of peripheral serotonin, 5HT-sublines also displayed constituve alteration in brain 5-HT homeostasis. Thus we have demonstrated previously that animals from the high-5HT subline exhibit increased anxiety-like behaviour; however, no measurable differences in baseline functionality or expression of $5-\mathrm{HT}_{1 \mathrm{~A}}$ receptors between sublines were found. Here, we examined the response of 5HT-sublines to the chronic administration of fluoxetine.

\footnotetext{
* Correspondence: lipa.cicin-sain@irb.hr

Department of Molecular Biology, Ruđer Bošković Institute, 10000 Zagreb, Croatia
}

(c) 2012 Kesić et al; licensee BioMed Central Ltd. This is an Open Access article distributed under the terms of the Creative Commons Attribution License (http://creativecommons.org/licenses/by/2.0), which permits unrestricted use, distribution, and reproduction in any medium, provided the original work is properly cited.

\section{Methods}

We treated male rats from high-5HT and low-5HT sublines with fluoxetine $(6 \mathrm{mg} / \mathrm{kg}$, i.p) for 27 days. Anxietylike behavior was evaluated $24 \mathrm{~h}$ after the $23 \mathrm{rd}$ injection by means of the elevated-plus maze paradigm. The expression of SERT and 5- $\mathrm{HT}_{1 \mathrm{~A}}$ receptors was assessed in frontal cortices, $48 \mathrm{~h}$ after the last injection, using RT-PCR. At the same time point we also measured cortical 5-HT levels using an ELISA assay.

\section{Results}

Fluoxetine-induced reduction of anxiety-like behavior, measured as increased time spent in open arms, was only observed in high-5HT animals. Furthermore, chronic fluoxetine administration increased the expression of SERT in high-5HT animals and decreased it in animals from the low-5HT subline. The expression of cortical 5$\mathrm{HT}_{1 \mathrm{~A}}$ receptors was not affected in high-5HT animals, whereas in the low-5HT subline a reduction in expression was noted. Tissue levels of 5-HT in fluoxetine-treated animals were significantly higher in the high- $5 \mathrm{HT}$ subline as compared to the low-5HT subline.

\section{Conclusions}

The present data demonstrate that fluoxetine-induced changes in 5-HT regulation exhibit clear differences between hypo- and hyperserotonergic rats. These results may contribute to the better understanding of the interindividual variability in the outcome of psychotherapy with serotonin-related drugs. 


\section{Acknowledgements}

This work was supported by the Croatian Ministry of Science, Education and Sport, grants no. 098-1081870-2395 and 098-1081870-2397.

Published: 17 September 2012

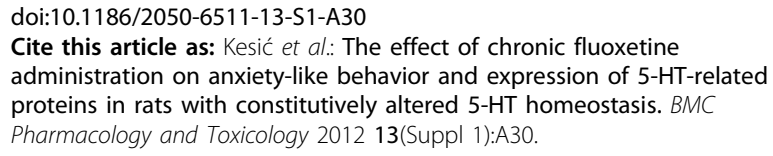

Submit your next manuscript to BioMed Central and take full advantage of:

- Convenient online submission

- Thorough peer review

- No space constraints or color figure charges

- Immediate publication on acceptance

- Inclusion in PubMed, CAS, Scopus and Google Scholar

- Research which is freely available for redistribution

Submit your manuscript at www.biomedcentral.com/submit 